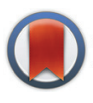

CrossMark

$\leftarrow$ click for updates

Cite this: Dalton Trans., 2016, 45 3260

Received 8th January 2016,

Accepted 15th January 2016

DOI: 10.1039/c6dt00100a

www.rsc.org/dalton

\section{Unusual dimer formation of cyclometalated ruthenium NHC $p$-cymene complexes $\uparrow$}

\author{
David Schleicher, ${ }^{a}$ Alexander Tronnier, ${ }^{a}$ Hendrik Leopold, ${ }^{a}$ Horst Borrmann ${ }^{\mathrm{b}}$ and \\ Thomas Strassner*a
}

\begin{abstract}
We present the synthesis and structural characterization of novel ruthenium complexes containing $\mathrm{C}^{\wedge} \mathrm{C}^{*}$ cyclometalated $\boldsymbol{N}$-heterocyclic carbene ligands, $\eta^{6}$-arene ( $p$-cymene) ligands and one bridging chlorine ion. Complexes of the general formula [Ru(p-cymene) $\left.\left(C^{\wedge} C^{*}\right) C l\right]$ were prepared via a one-pot synthesis using in situ transmetalation from the correspondent silver NHC complexes. These complexes react with sodium tetrakis[3,5-bis(trifluoromethyl)phenyl]borate $\left(\mathrm{NaBAr}_{4}{ }_{4}\right)$ to form dinuclear complexes of the general structure [Ru( $p$-cymene)( $\left.C^{\wedge} C^{*}\right)-\mu-\mathrm{Cl}$-( $p$-cymene)$\left.\left(C^{\wedge} C^{*}\right) R u\right]^{+}\left[B A r^{F}\right]^{-}$. Solid-state structures confirm that the pseudotetrahedral coordination around the metal center with the $\eta^{6}$-ligand aligned perpendicularly to the $C^{\wedge} C^{*}$ ligand and the $i-\operatorname{Pr}$ group "atop" is retained in the bimetallic complexes.
\end{abstract}

Over the last few years ruthenium complexes, especially with strong electron-donating ligands like $N$-heterocyclic carbenes (NHC) and/or cyclometalating moieties, have gained widespread interest for their diverse catalytic activity, e.g. in transfer hydrogenation ${ }^{1}$ metathesis, ${ }^{2}$ and water oxidation. ${ }^{3}$ Especially NHC complexes allow for a wide range of steric and electronic control at the metal center and are more stable than other widely used neutral donors like phosphine ligands. ${ }^{1 a, 4}$ Cyclometalated $\mathrm{Ru}(\mathrm{II})$ complexes have also become more and more interesting as sensitizers in dye-sensitized solar cells. ${ }^{5}$ Here the cyclometalating ligands have several advantages such as raising the HOMO/LUMO levels for more efficient electron transport into the $\mathrm{TiO}_{2}$ substrate as well as from the redox pair responsible for the regeneration of the dye. The chelating effect also increases their long term stability compared to complexes with monodentate thiocyanate ligands. Moreover, in the last few years ruthenium arene complexes with either cyclo-

\footnotetext{
${ }^{a}$ Physikalische Organische Chemie, Technische Universität Dresden, 01069 Dresden, Germany.E-mail: thomas.strassner@chemie.tu-dresden.de

${ }^{b}$ Max-Planck-Institut für Chemische Physik fester Stoffe, 01187 Dresden, Germany. E-mail: horst.borrmann@cpfs.mpg.de

$\dagger$ Electronic supplementary information (ESI) available: Detailed experimental and crystallographic methods as well as NMR data of the complexes. CCDC 1441834, 1441835 and 1441914. For ESI and crystallographic data in CIF or other electronic format see DOI: 10.1039/c6dt00100a
}

metalating or NHC ligands were used in cytotoxicity and anticancer studies. ${ }^{6}$

Since our group has a long-standing interest in alkyl-arylimidazolium salts $^{7}$ and their respective transition metal (especially palladium $^{8}$ and platinum $^{9}$ ) complexes, we developed a synthetic one-pot route to ruthenium complexes featuring these $\mathrm{C}^{\wedge} \mathrm{C}^{*}$ ligand motifs. It should be noted that quite recently the group of Wang published similar complexes $^{10}$ as intermediates in the synthesis of highly substituted imidazolium salts following up on their earlier report on $\mathrm{sp}^{2}$ and $\mathrm{sp}^{3}$ CH-activation in ruthenium NHC complexes. ${ }^{11}$ Furthermore Choudhury et al. reported cyclometalated $\mathrm{Ru}(\mathrm{II})$ NHC complexes based on a pyridyl ligand for studies of electronic properties of dinuclear complexes. ${ }^{12}$

To study the reactivity of the $\left[\mathrm{Ru}(p\right.$-cymene $\left.)\left(\mathrm{C}^{\wedge} \mathrm{C}^{*}\right) \mathrm{Cl}\right] \mathrm{com}$ plexes, we wanted to remove the chlorine ligand. Reaction with the sodium salt of the bulky non-coordinating anion $\left[\mathrm{BAr}_{4}^{\mathrm{F}}\right]^{-}-$ to our surprise - did not lead to the cationic species $[\mathrm{Ru}(p$ cymene $\left.)\left(\mathrm{C}^{\wedge} \mathrm{C}^{*}\right)\right]^{+}\left[\mathrm{BAr}^{\mathrm{F}}{ }_{4}\right]^{-}$and sodium chloride, but rather gave rise to the formation of a ruthenium $\mu$-chloro bridged structure consisting of two ruthenium centers with one $\mathrm{C}^{\wedge} \mathrm{C}^{*}$ ligand and $p$-cymene each and only one bridging chlorine ion. The single positive charge of the product complex is compensated by one $\left[\mathrm{BAr}_{4}^{\mathrm{F}}\right]^{-}$counter ion. This type of ruthenium dimers with only one bridging ion - to the best of our knowledge - has been described only twice in the literature before. More than 40 years ago Haines et al. reported the synthesis of halogen-bridged ruthenium piano stool complexes with $\eta^{6}$-benzene and carbon monoxide ligands. ${ }^{13}$ And quite recently Oestereich described the formation of a ruthenium dinuclear species bearing a chelating $\eta^{6}$-arene-sulfur and a phosphine ligand, which was catalytically active in hydrodefluorination, ${ }^{14}$ while the groups of Peris and Crabtree reported a dinuclear ruthenium complex with one bridging chlorine ion and an additional bridging bis-NHC ligand. ${ }^{15}$

We present the synthetic one-pot route to the $\left[\mathrm{Ru}(p\right.$-cymene $\left.)\left(\mathrm{C}^{\wedge} \mathrm{C}^{*}\right) \mathrm{Cl}\right]$ complexes depicted in scheme 1 . It starts from a mixture of the widely used $\left[\operatorname{RuCl}_{2}\left(\eta^{6}-p \text {-cymene }\right)\right]_{2}$ precursor and the corresponding 1-alkyl-3-aryl imidazolium 

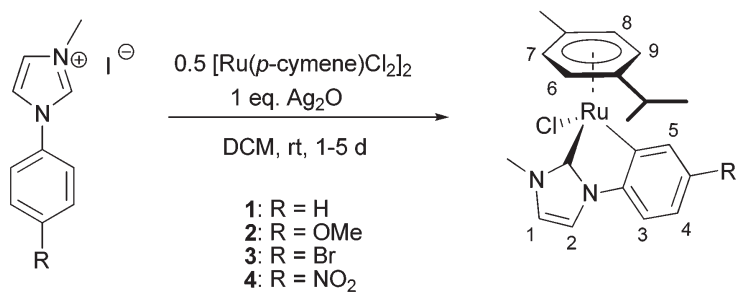

Scheme 1 Synthetic route to cyclometalated Ru NHC complexes via transmetalation from silver carbene complexes; numbers correspond to NMR assignments.

iodide in dry dichloromethane. Addition of one equivalent of silver(I) oxide to the stirred suspension at room temperature under inert atmosphere and exclusion of light results in the formation of the desired ruthenium compounds. It should be noted that an isolation of the intermediate $\mathrm{Ag}(\mathrm{NHC})$ complexes and subsequent transmetalation was not found to give any improvement in overall yields.

The crude product is (with the exception of 1) subjected to column chromatography $\left(\mathrm{SiO}_{2}, \mathrm{DCM} / \mathrm{MeOH} 10: 1\right.$; yellow to orange band with $\left.R_{\mathrm{f}}=0.90-0.95\right)$ and the resulting yellow solid is dissolved in little amounts of THF, filtered over basic alumina, and slowly precipitated with pentane to give analytically pure samples.

The isolated complexes are stable under ambient conditions. However, solutions in wet solvents (especially in slightly acidic ones like chloroform) slowly turn from yellow to green and ultimately to dark blue with complete decomposition of the complexes. These observations are in accordance to those reported by Albrecht et al. ${ }^{16}$ for similar dinuclear species.

Yellow-orange crystals of $\mathbf{1}$ and $\mathbf{2}$ were obtained by slow diffusion of pentane into a solution of the complex in a mixture of dichloromethane/diethyl ether. Their structures are shown in Fig. 1 and 2, crystallographic details can be found in

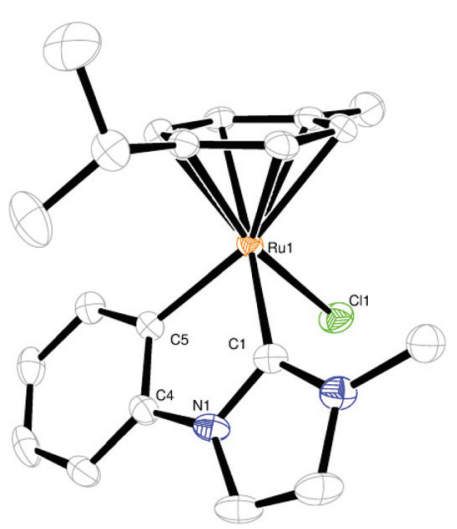

Fig. 1 ORTEP of 1 in the solid state. Thermal ellipsoids are drawn at the $50 \%$ probability level, $\mathrm{H}$ atoms are omitted for clarity. Selected bond lengths [Å], angles and dihedral angles [ $\left.{ }^{\circ}\right]: \mathrm{Ru}(1)-\mathrm{Cl}(1) 2.411(10) ; \mathrm{Ru}(1)-\mathrm{C}(1)$ 2.026(3); $\mathrm{Ru}(1)-\mathrm{C}(5)$ 2.073(3); Ru(1)-Centroid (cymene) 1.727; C(1)-Ru(1)$\mathrm{C}(5) 76.7(12) ; \mathrm{C}(1)-\mathrm{N}(1)-\mathrm{C}(4)-\mathrm{C}(5)-0.3(4)$.

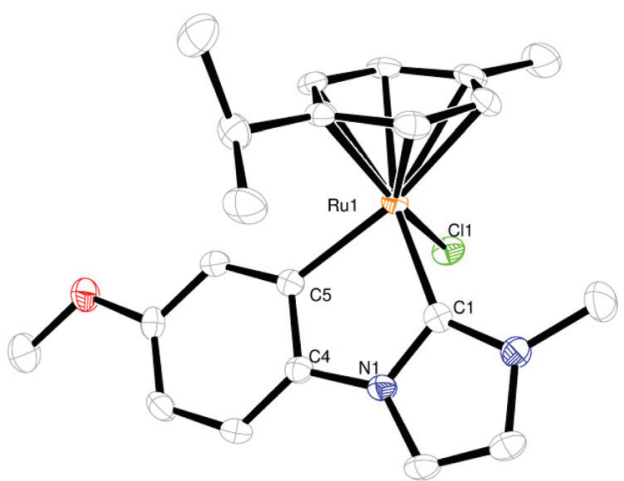

Fig. 2 ORTEP of 2 in the solid state. Thermal ellipsoids are drawn at the $50 \%$ probability level, $\mathrm{H}$ atoms are omitted for clarity. Selected bond lengths $[\AA ̊]$, angles and dihedral angles [ $\left.{ }^{\circ}\right]$ : Ru(1)-Cl(1) 2.4294(8); Ru(1)$\mathrm{C}(1)$ 2.011(3); $\mathrm{Ru}(1)-\mathrm{C}$ (5) 2.076(3); Ru(1)-Centroid 1.724; C(1)-Ru(1)-C(5) 77.25(11); $\mathrm{C}(1)-\mathrm{N}(1)-\mathrm{C}(4)-\mathrm{C}(5) 0.7(3)$.

the ESI (Tables S1 and S2 $\dagger$ ). The complexes show the typical "piano-stool" geometry with a pseudo-tetrahedral coordination sphere at the ruthenium center. The bite angle is significantly smaller than $90^{\circ}$ (approx. $77^{\circ}$ ) resulting in a "yaw"-distortion ${ }^{17}$ at the carbene of $9.1^{\circ}$ for $\mathbf{1}$ and $9.8^{\circ}$ for 2 .

Comparison of $\mathrm{Ru}-\mathrm{C}$ bond lengths shows a slightly shorter distance to the carbene carbon atom than to the (anionic) phenyl carbon atom due to $\pi$-back donation. All these structural findings are in good agreement with previously reported similar complexes. ${ }^{11,16,18}$

The synthesis of the corresponding dimers (see Scheme 2) is again carried out in dry dichloromethane at room temperature using a slight excess (relative to 0.5 equivalents) of the $\mathrm{BAr}^{\mathrm{F}}$ salt. Using 1 or 1.1 equivalents of the sodium salt gives the exact same complexes and still doesn't lead to the formation of the cationic ruthenium complexes. Prolonging the reaction time however causes slow decomposition of the complexes, which can be clearly observed by a darkening of the reaction mixture.

The obtained complexes are readily soluble in diethyl ether, from which they can be crystallized by slow addition of pentane. Purification can be achieved by filtering the ether solutions consecutively through small pads of Celite and basic alumina. The dimers are air stable as solids, but solutions in solvents like chloroform, ethanol, and acetone turn blue quite rapidly. We confirmed the structure of the synthesized

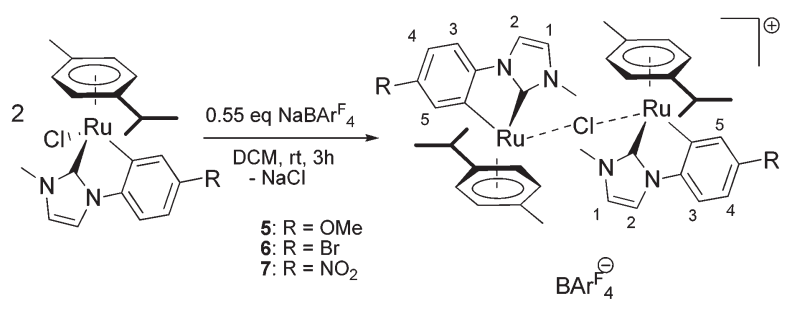

Scheme 2 Synthesis of the ruthenium dimers. 
dinuclear compounds by 2D-NMR experiments, elemental analyses as well as solid state structure determination. NMR spectra of 5 and 6 (recorded in deuterated benzene) show that the signals for the $\mathrm{C}^{\wedge} \mathrm{C}^{*}$ ligand(s) don't shift significantly $(<0.5 \mathrm{ppm})$ in comparison to the respective monomers. However, the signals for the aromatic protons of the $p$-cymene ring show a different pattern compared to the monomeric complexes. Two of the signals (two adjacent protons on "one side") are shifted upfield by almost $2 \mathrm{ppm}$. This is evidence for their strong electronic shielding (in the "inner part" of the dinuclear complex) and clearly indicates that the dimers are also stable in solution. Complex 7 is barely soluble in benzene and we therefore measured the NMR spectra in deuterated acetonitrile. Interestingly, in this (coordinating) solvent different signal patterns are observed for the two metal centers (see ESI $\dagger$ for details), which is an indication of a slightly different arrangement of the $\eta^{6}$ ligand. This effect can also be observed when dissolving complexes $\mathbf{5}$ or $\mathbf{6}$ in acetonitrile, but these solutions quite rapidly turn blue, showing decomposition.

The solid state structure of complex 6 (see Fig. 3, crystallographic details given in the ESI, Table S3†) shows that the geometry around both ruthenium centers is generally retained in regard to the monomeric structures. The complex still consists of two piano-stool "hemispheres" sharing the central chlorine ion. Bond distances and angles differ only slightly from the monomeric complexes. The bridging angle between both ruthenium atoms and the chlorine ion is very similar to the one reported by Peris $\left(126.43(4)^{\circ}\right)^{15}$ and significantly larger than the bridging angles in the $\left[\operatorname{RuCl}_{2}\left(\eta^{6}-p \text {-cymene }\right)\right]_{2}$ dimer, which are approx. $97-98^{\circ} .{ }^{19}$ One of the most interesting features about these dinuclear compounds is the opposing direction of the ligands around the two metal centers. In this way they can arrange in a sterically much more favorable position

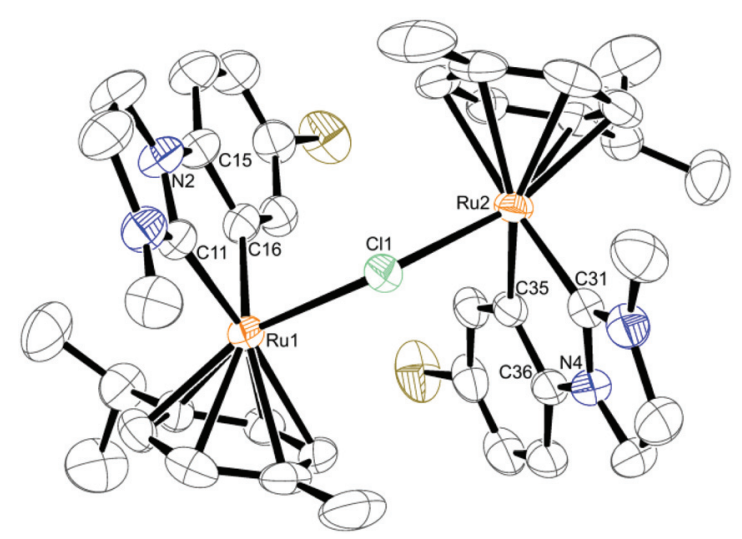

Fig. 3 ORTEP of 6 in the solid state. Thermal ellipsoids are drawn at the $30 \%$ probability level, $\mathrm{H}$ atoms and the anion are omitted for clarity. Selected bond lengths $[\AA ̊]$, angles and dihedral angles $\left[^{\circ}\right]$ : $\mathrm{Ru}(1)-\mathrm{Cl}(1)$ 2.4490(9); $\mathrm{Ru}(2)-\mathrm{Cl}(1)$ 2.4467(9); $\mathrm{Ru}(1)-\mathrm{C}(11)$ 2.035(4); $\mathrm{Ru}(1)-\mathrm{C}(16)$ 2.073(4); $\mathrm{Ru}(2)-\mathrm{C}(31)$ 2.050(4); $\mathrm{Ru}(2)-\mathrm{C}(35)$ 2.075(3); Ru(1)-Centroid (cymene) 1.735; $\mathrm{Ru}(2)-C e n t r o i d ~(c y m e n e)$ 1.733; $\mathrm{Ru}(2)-\mathrm{Cl}(1)-\mathrm{Ru}(1)$ 129.28(4); C(11)-Ru(1)-C(16) 76.94(16); C(31)-Ru(2)-C(35) 76.30(16); $\mathrm{C}(11)-\mathrm{N}(2)-\mathrm{C}(15)-\mathrm{C}(16) 2.2(6) ; \mathrm{C}(31)-\mathrm{N}(4)-\mathrm{C}(36)-\mathrm{C}(35)-0.4(5)$. than with adjacent $\eta^{6}$-arene ligands. Moreover, this leads to an almost ball-like geometry of the complex, which together with the perfectly spherical $\left[\mathrm{BAr}_{4}^{\mathrm{F}}\right.$ ] anions provides a good means for optimal packing in the crystal (see ESI, Fig. S1†).

In conclusion we prepared cyclometalated ruthenium NHC complexes via a one-pot transmetalation route. The $\left[\mathrm{Ru}(p\right.$-cymene $\left.)\left(\mathrm{C}^{\wedge} \mathrm{C}^{*}\right) \mathrm{Cl}\right]$ complexes are generally obtained in moderate to good yields and can be stored under ambient conditions.

Abstraction of the halide ligand proved to be difficult and several synthetic strategies were not successful. However, the reaction of these complexes with sodium tetrakis[3,5-bis(trifluoromethyl)phenyl]borate lead to the formation of a novel class of ruthenium(II) dimers bridged only by a single chlorine ion. Their molecular structure, which was unambiguously confirmed by several analytical methods, shows a distorted pseudo-tetrahedral geometry around the ruthenium centers and weak $\mathrm{CH}-\pi$ interactions between the aromatic protons of the cymene ligand and the cyclometalated ring on the opposite ruthenium center.

\section{Notes and references}

1 (a) V. Dragutan, I. Dragutan, L. Delaude and A. Demonceau, Coord. Chem. Rev., 2007, 251, 765-794; (b) N. Pannetier, J.-B. Sortais, J.-T. Issenhuth, L. Barloy, C. Sirlin, A. Holuigue, L. Lefort, L. Panella, J. G. de Vries and M. Pfeffer, Adv. Synth. Catal., 2011, 353, 2844-2852; (c) H. D. Velazquez and F. Verpoort, Chem. Soc. Rev., 2012, 41, 7032-7060; (d) W. B. Cross, C. G. Daly, Y. Boutadla and K. Singh, Dalton Trans., 2011, 40, 97229730; (e) M. Delgado-Rebollo, D. Canseco-Gonzalez, M. Hollering, H. Mueller-Bunz and M. Albrecht, Dalton Trans., 2014, 43, 4462-4473; $(f)$ N. Ding and T. S. A. Hor, Dalton Trans., 2010, 39, 10179-10179; $(g)$ H. Ohara, W. W. N. O, A. J. Lough and R. H. Morris, Dalton Trans., 2012, 41, 8797-8808; (h) X.-H. Zhu, L.-H. Cai, C.-X. Wang, Y.-N. Wang, X.-Q. Guo and X.-F. Hou, J. Mol. Catal. A: Chem., 2014, 393, 134-141; (i) S. Enthaler, R. Jackstell, B. Hagemann, K. Junge, G. Erre and M. Beller, J. Organomet. Chem., 2006, 691, 4652-4659; (j) J. DePasquale, M. Kumar, M. Zeller and E. T. Papish, Organometallics, 2013, 32, 966-979; (k) F. E. Fernández, M. C. Puerta and P. Valerga, Organometallics, 2012, 31, 6868-6879; (l) D. Gnanamgari, E. L. O. Sauer, N. D. Schley, C. Butler, C. D. Incarvito and R. H. Crabtree, Organometallics, 2009, 28, 321-325; $(m)$ N. Pannetier, J.-B. Sortais, P. S. Dieng, L. Barloy, C. Sirlin and M. Pfeffer, Organometallics, 2008, 27, 5852-5859; (n) Y.-B. Lai, C.-S. Lee, W.-J. Lin, A. R. Naziruddin and W.-S. Hwang, Polyhedron, 2013, 53, 243-248.

2 (a) R. Kadyrov, Chem. - Eur. J., 2013, 19, 1002-1012; (b) X. Sauvage, Y. Borguet, A. F. Noels, L. Delaude and A. Demonceau, Adv. Synth. Catal., 2007, 349, 255-265; (c) C. Lübbe, A. Dumrath, H. Neumann, M. Beller and 
R. Kadyrov, ChemCatChem, 2014, 6, 105-108; (d) Y. Kong, S. Xu, H. Song and B. Wang, Organometallics, 2012, 31, 5527-5532.

3 L. Bernet, R. Lalrempuia, W. Ghattas, H. Mueller-Bunz, L. Vigara, A. Llobet and M. Albrecht, Chem. Commun., 2011, 47, 8058-8060.

4 (a) V. Dragutan and I. Dragutan, Platinum Metals Rev., 2005, 49, 123-137; (b) M. N. Hopkinson, C. Richter, M. Schedler and F. Glorius, Nature, 2014, 510, 485-496.

5 (a) T. Funaki, H. Kusama, N. Onozawa-Komatsuzaki, K. Kasuga, K. Sayama and H. Sugihara, Eur. J. Inorg. Chem., 2014, 2014, 1303-1311; (b) S. H. Wadman, J. M. Kroon, K. Bakker, M. Lutz, A. L. Spek, G. P. M. van Klink and G. van Koten, Chem. Commun., 2007, 1907-1909; (c) T. Bessho, E. Yoneda, J.-H. Yum, M. Guglielmi, I. Tavernelli, H. Imai, U. Rothlisberger, M. K. Nazeeruddin and M. Grätzel, J. Am. Chem. Soc., 2009, 131, 5930-5934; (d) K. C. D. Robson, B. D. Koivisto, A. Yella, B. Sporinova, M. K. Nazeeruddin, T. Baumgartner, M. Grätzel and C. P. Berlinguette, Inorg. Chem., 2011, 50, 5494-5508; (e) K. C. D. Robson, P. G. Bomben and C. P. Berlinguette, Dalton Trans., 2012, 41, 7814-7829; $(f)$ P. G. Bomben, T. J. Gordon, E. Schott and C. P. Berlinguette, Angew. Chem., Int. Ed., 2011, 50, 10682-10685; (g) P. G. Bomben, J. Borau-Garcia and C. P. Berlinguette, Chem. Commun., 2012, 48, 5599-5601; (h) P. G. Bomben, K. C. D. Robson, B. D. Koivisto and C. P. Berlinguette, Coord. Chem. Rev., 2012, 256, 1438-1450; (i) P. G. Bomben, K. D. Thériault and C. P. Berlinguette, Eur. J. Inorg. Chem., 2011, 2011, 18061814; (j) T. Funaki, H. Funakoshi, O. Kitao, N. OnozawaKomatsuzaki, K. Kasuga, K. Sayama and H. Sugihara, Angew. Chem., Int. Ed., 2012, 51, 7528-7531; (k) B. Schulze, D. Escudero, C. Friebe, R. Siebert, H. Görls, S. Sinn, M. Thomas, S. Mai, J. Popp, B. Dietzek, L. González and U. S. Schubert, Chem. - Eur. J., 2012, 18, 4010-4025; (l) C.-W. Hsu, S.-T. Ho, K.-L. Wu, Y. Chi, S.-H. Liu and P.-T. Chou, Energy Environ. Sci., 2012, 5, 7549-7554; ( $m$ ) J.-J. Kim, H. Choi, S. Paek, C. Kim, K. Lim, M.-J. Ju, H. S. Kang, M.-S. Kang and J. Ko, Inorg. Chem., 2011, 50, 11340-11347.

6 (a) G. Lv, L. Guo, L. Qiu, H. Yang, T. Wang, H. Liu and J. Lin, Dalton Trans., 2015, 44, 7324-7331; (b) K. J. Kilpin, S. Crot, T. Riedel, J. A. Kitchen and P. J. Dyson, Dalton Trans., 2013, 43, 1443-1443; (c) L. Oehninger,
M. Stefanopoulou, H. Alborzinia, J. Schur, S. Ludewig, K. Namikawa, A. Munoz-Castro, R. W. Koster, K. Baumann, S. Wolfl, W. S. Sheldrick and I. Ott, Dalton Trans., 2013, 1657-1666; (d) J. Dinda, S. D. Adhikary, G. Roymahapatra, K. K. Nakka and M. K. Santra, Inorg. Chim. Acta, 2014, 413, 23-31; (e) F. Hackenberg, H. Müller-Bunz, R. Smith, W. Streciwilk, X. Zhu and M. Tacke, Organometallics, 2013, 32, 5551-5560; $(f)$ B. Pena, A. David, C. Pavani, M. S. Baptista, J.-P. Pellois, C. Turro and K. R. Dunbar, Organometallics, 2014, 33, 1100-1103; (g) B. A. Albani, B. Peña, K. R. Dunbar and C. Turro, Photochem. Photobiol. Sci., 2014, 13, 272-272.

7 S. Ahrens, A. Peritz and T. Strassner, Angew. Chem., Int. Ed., 2009, 48, 7908-7910.

8 D. Munz, A. Poethig, A. Tronnier and T. Strassner, Dalton Trans., 2013, 42, 7297-7297.

9 Y. Unger, D. Meyer, O. Molt, C. Schildknecht, I. Münster, G. Wagenblast and T. Strassner, Angew. Chem., Int. Ed., 2010, 49, 10214-10216.

10 C. Ma, C. Ai, Z. Li, B. Li, H. Song, S. Xu and B. Wang, Organometallics, 2014, 33, 5164-5172.

11 C. Zhang, Y. Zhao, B. Li, H. Song, S. Xu and B. Wang, Dalton Trans., 2009, 5182-5189.

12 M. Mondal, T. K. Ranjeesh, S. K. Gupta and J. Choudhury, Dalton Trans., 2014, 43, 9356-9356.

13 R. J. Haines and A. L. Du Preez, J. Chem. Soc., Dalton Trans., 1972, 944-948.

14 T. Stahl, H. F. T. Klare and M. Oestreich, J. Am. Chem. Soc., 2013, 135, 1248-1251.

15 M. Poyatos, W. McNamara, C. Incarvito, E. Clot, E. Peris and R. H. Crabtree, Organometallics, 2008, 27, 21282136.

16 L. Mercs, A. Neels, H. Stoeckli-Evans and M. Albrecht, Inorg. Chem., 2011, 50, 8188-8196.

17 C. H. Leung, C. D. Incarvito and R. H. Crabtree, Organometallics, 2006, 25, 6099-6107.

18 (a) D. Enders, H. Gielen, G. Raabe, J. Runsink and H. Henrique Teles, Chem. Ber., 1997, 130, 1253-1260; (b) F. Simal, D. Jan, L. Delaude, A. Demonceau, M.-R. Spirlet and A. F. Noels, Can. J. Chem., 2001, 79, 529535; (c) K. Ogata, S. Inomata and S.-I. Fukuzawa, Dalton Trans., 2013, 42, 2362-2362.

19 C. S. Allardyce, P. J. Dyson, D. J. Ellis, P. A. Salter and R. Scopelliti, J. Organomet. Chem., 2003, 668, 35-42. 